\title{
Evaluation of the nutrient status of wheat plants
}

\author{
M. Kostic ${ }^{1}$, W. Dijkshoorn ${ }^{2}$ and C. T. de Wit ${ }^{2}$ \\ 1 Institute for Wheat Research, Kragujevac, Yugoslavia \\ 2 Institute for Biological and Chemical Research on Field Crops and Herbage (I.B.S.), \\ Wageningen, The Netherlands
}

Received 25 March, 1967

\section{Summary}

The balance of the principal ionic constituents in plants is reviewed in relation to the requirements for each of the elements, and for total accumulation as reflected in the total cation content (C), the inorganic anion conent (A) and the organic anion content $(\mathrm{C}-\mathrm{A})$.

The balance in young wheat plants is investigated by means of adding various combinations of the principal ions to the soil.

A summary of tests on adequacy of supply with the principal nutrient ions and of accumulation of cations, inorganic anions and organic anions, based on critical values for contents in the plant material, is presented for diagnosing the nutrient status in relation to capacity for maximum growth.

\section{Introduction}

Evidence was obtained that the grain yield is often increased when the early growth of wheat plants is retarded by a limited supply with nitrogen. An example is summarized in Fig. 1, where straw and grain yields have been plotted against the amount of nitrogen supplied in the fertilizer. The solid lines show the relation for single applications at sowing of $0,60,90$ or $120 \mathrm{~kg} \mathrm{~N} / \mathrm{ha}$. The broken lines refer to an application at sowing of $30 \mathrm{~kg} \mathrm{~N} / \mathrm{ha}$, and supplements of 30,60 or $90 \mathrm{~kg} \mathrm{~N} / \mathrm{ha}$ applied at the beginning of shooting.

The split applications of nitrogen led to lower straw and higher grain yields compared with the single dressings at sowing. Since the same was observed on CCCtreated plots without lodging suppression of lodging by split applications could not have been the only cause of the improved grain yields. Apparently, moderate dressing with nitrogen at the onset of growth, followed by supplementary dressings at shooting, may shift dry matter distribution in favour of the grain yield.

However, regulation of the time course of growth by split applications of nitrogen can be satisfactory only if at the time of the second application the other conditions are adequate to support maximum growth required after shooting.

One of these other conditions concerns the supply with major elements from the soil, as reflected in leaf composition with respect to $\mathrm{K}, \mathrm{Na}, \mathrm{Mg}, \mathrm{Ca}$ and $\mathrm{NO}_{3}, \mathrm{Cl}, \mathrm{H}_{2} \mathrm{PO}_{4}$, $\mathrm{SO}_{4}$. A balance-sheet of these ions also yields the organic salt content $(\mathrm{C}-\mathrm{A})$ as the difference between the equivalents sum of inorganic cations (C) and the inorganic anions (A) in the tissues. Previous research showed that maximum growth may be 


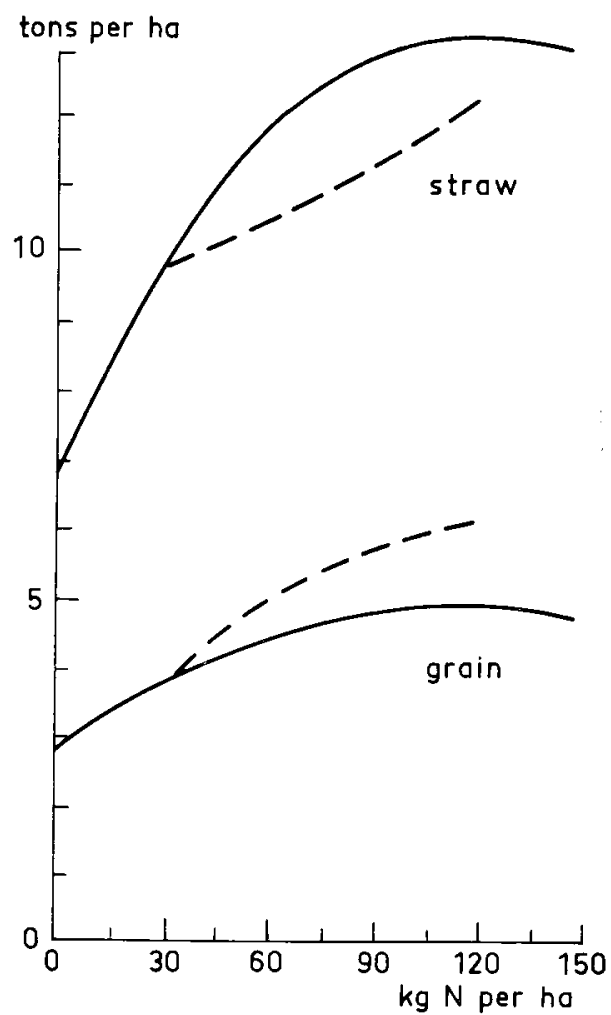

Fig. 1 Straw and grain yields of wheat, grown in the field with varying rates of $N$ applications (abscissae). Solid lines: all $N$ applied at sowing. Broken lines: $30 \mathrm{~kg} \mathrm{~N} / \mathrm{ha}$ at sowing, the remainder applied on July 6 at the beginning of shooting. Data of Jonker and de Jong (1966).

obtained only if the organic salt content is at the normal level (de Wit et al., 1963). In view of the perspectives of nitrogen-controlled growth it was considered useful to examine the ionic balance of wheat in the pre-shooting stage, to evaluate the normal organic salt content and to attempt to develop a key for diagnosing the nutrient status.

It seems useful first to review the main characteristics of the ionic balance and its response to different fertilizer formulas.

Among the anions phosphate is present as inorganic phosphate and in the form of phosphorylated organic compounds, but the ionic form of all phosphates may in good approximation be considered as $\mathrm{H}_{2} \mathrm{PO}_{4}-$. Phosphate absorbed distributes over the nucleoproteins and phospholipids, the TCA-soluble organic phosphates and free orthophosphate. In ryegrass the nucleoproteins (plus phospholipid) phosphorus was 0.025 gram atoms $\mathbf{P}$ per gram atom of protein nitrogen, the TCA-soluble organic phosphate 0.03 gram atoms $\mathbf{P}$ per $\mathrm{kg}$ of dry plant material, and the remainder was free orthophosphate (Dijkshoorn and Lampe, 1961). According to these figures the organic-phosphate content of plants with 3 gram atoms of organic nitrogen (mainly protein-nitrogen) will be $3 \times 0.025+0.03=0.1$ gram atoms $\mathbf{P}$ per $\mathrm{kg}$ dry matter.

From data on the relation between plant growth and phosphate fractions (Sokolov, 1945 ) it can be inferred that the phosphate requirement for maximum growth is about twice the amount transformed into organic phosphates. The plant need will then be 
0.2 gram atoms. Expressed as the more convenient meq. units, this requirement for growth will be 200 meq. $\mathrm{H}_{2} \mathrm{PO}_{4}$ per $\mathrm{kg}$ dry plant material. Therefore, values for phosphate greater than $200 \mathrm{meq} / \mathrm{kg}$ dry matter indicate adequate phosphate supply for plants with nitrogen below 3 gram atoms of organic $\mathrm{N}$ per $\mathrm{kg}$ dry matter.

Sulphate absorbed in excess of its metabolic conversion to non-ionic organic sulphur is retained by the tissues as inorganic sulphate. With shortage in the supply, the sulphate content drops by dilution and metabolic consumption, and plants deficient in sulphur have very low sulphate contents of about $12 \mathrm{meq} . / \mathrm{kg}$ dry matter (Dijkshoorn and van Wijk, 1967). Since some reserve in the tissues seems desirable, inorganic-sulphate values of less than 20 meq./ $\mathrm{kg}$ dry matter should be considered critical for growth.

The chloride requirement for growth is very low (Ulrich and Ohki, 1956) and is always met in soil-grown plants. When supplied in the fertilizer, chloride may accumulate in high concentrations in the tissues.

When nitrogen is in adequate supply, the organic-nitrogen content of young wheat plants is in the range of 3000 to 4000 milligram atoms of $\mathrm{N}$ per $\mathrm{kg}$ dry matter. It originates from absorbed nitrate or ammonium and is conveniently expressed as the meq. of these ions which give the same numerical value as milligram atoms of $\mathrm{N}$. Ammonium absorbed is nearly completely transformed into organic $\mathrm{N}$, but if nitrate acts as the source of nitrogen some of it is retained in the ionic form by the tissues. If during growth nitrate becomes exhausted in the supply there is a subsequent fall in nitrate concentration in the tissues as a result of metabolic consumption and dilution (Dijkshoorn, 1958). In grass, a nitrate content of 100 meq. $/ \mathrm{kg}$ dry matter is indicative of sufficient supply (van Burg, 1966), but depending on plant species and ion supply the nitrate content is often much higher.

Of these absorbed anions, some of the nitrate and sulphate, and all of the chloride and phosphate is retained in the ionic form. The quantities are obtained by analyses on nitrate, chloride, total phosphate and (inorganic) sulphate in the plant material. The sum of meq. $\mathrm{NO}_{3}-+\mathrm{Cl}-+\mathrm{H}_{2} \mathrm{PO}_{4}-+\mathrm{SO}_{4}=$ is called the inorganic anion content A. For practical reasons, this value includes total phosphorus. The organic phosphates are thus grouped under the anions $A$, since their ionic form is similar to orthophosphate in the range of tissue $\mathrm{pH}$. The organic anions of carboxylate character (see below) are then placed in one group of carboxylates only.

Of the cations absorbed, potassium, sodium, magnesium and calcium contribute in significant amounts to the final cation content of the tissues. Irrespective of their distribution at the cellular level, their dissolved or undissolved state or linkage with other constituents, they contribute as metallic cations to the formation of the various salts present in the tissues. The sum of meq. $\mathrm{K}++\mathrm{Na}^{+}+\mathrm{Mg}^{+}++\mathrm{Ca}^{+}+$represents the total cation content $\mathrm{C}$ of the plant material.

In plant tissues there is always an excess of the cations (C) over the inorganic anions (A) and this excess is balanced by organic anions. It has been found that the organic salt content $(\mathrm{C}-\mathrm{A})$, inferred from the balance of inorganic ions, consists of carboxylates only, and originates mainly from the common organic plant acids, being recovered as malate, citrate, oxalate etc. (van Tuil, 1965).

Previous research on the relation between growth and the ionic balance showed that gramineous plants tend to maintain an organic salt content $(\mathrm{C}-\mathrm{A})$ of a certain value which, depending on the species, lies in the range of $800-1000 \mathrm{meq} . / \mathrm{kg}$ dry matter. This organic salt content has been named the normal.

With adequate nutrient supply the normal organic salt content is maintained during 
the vegetative growth of grass plants. It can be reduced to a subnormal level by a change in the nutrient supply. It appeared that with such fertilizer formulas maximum growth was never obtained. Apparently, maximum-growth capacity requires a nutritional status which, among other characteristics, will enable the plant to maintain its normal organic salt content. A fall in (C-A) to values less that the normal is a sign of nutritional stress caused by shortage or excess of nutrients which affect the (C-A) (de Wit et al., 1963).

One of the conditions required for maintaining the normal $(C-A)$ content is a sufficient uptake of cations (C). According to data of Lundegårdh (1951), Broeshart and van Schouwenburg (1961), Garner et al. (1930), Key et al. (1962), and others, the minimum contents of magnesium and calcium are in the order of 50 and $100 \mathrm{meq} . / \mathrm{kg}$ dry matter, respectively, and values above $100 \mathrm{meq} / \mathrm{kg}$ dry matter may be considered adequate for the specific requirements. For potassium, the minimum content is about 200 meq. $/ \mathrm{kg}$ dry matter (van Tuil, 1965).

Compared with the other cations potassium is most readily absorbed by gramineous plants as the main constituent of the cation content $C$. Since potassium in the tissues can be made to vary considerably, the total cation content $\mathrm{C}$ is often much interfered with by the presence or absence of sufficient potassium.

The plant need for cations is conditioned by its efforts to maintain the normal organic salt content $(\mathrm{C}-\mathrm{A})$ and depends on the anion content $\mathrm{A}$. If the latter is raised by an increased accumulation of inorganic anions as e.g. chloride, nitrate, more of the cations are required to keep $(\mathrm{C}-\mathrm{A})$ at the normal level. Since potassium aids in the uptake of cations to a considerable extent, the potassium requirement will depend to a large extent on the inorganic anion content, and there will be no distinct potassium concentration of adequacy in the tissues valid under different conditions of ionic supply.

It is therefore common experience that growth can often be improved by an increase in potassium from any initial value in the range of, say, 200 to 1000 meq. $\mathrm{K} / \mathrm{kg}$ dry matter, provided that $(\mathrm{C}-\mathrm{A})$ is less than the normal, and is raised with the increase in potassium. The plant need for potassium is therefore dependent on its inorganic anion content, and is conditioned by its particular ability to readily supply extra cation equivalents by uptake, if required for the further maintenance of the normal (C-A) content.

Some gramineous species are able to accumulate sodium in large amounts but they do so only when they are deficient of potassium. In this case, potassium in the tissues may fall below the minimum content of $200 \mathrm{meq} / \mathrm{kg}$ dry matter, as a result of further dilution by extra growth initiated by sodium (Lehr and Wybenga, 1958; de Wit et al., 1963).

At sufficient supply a large proportion of ion absorption is occupied by the nitrogenous ions nitrate or ammonium.

With nitrate the uptake of anions proceeds in large quantities and the salt cation uptake is enhanced to balance the anion uptake. The nitrate absorbed is for the greater part metabolized. Only some of it is retained in the ionic form as unchanged nitrate which contributes to the final inorganic anion content in the tissues. The result is that $(C-A)$ accumulation is enhanced. For this reason nitrate nutrition will effectively support maintenance of the normal organic salt content.

With ammonium a large quantity of salt cations, including ammonium, is absorbed and this will promote the uptake of anions to balance the increased cation uptake. The ammonium absorbed is metabolized and since the uptake of potassium, sodium, 
magnesium and calcium, which compose the final cation content $\mathrm{C}$ in the tissues, is depressed by the large uptake of ammonium, the accumulation of organic salts (C-A) becomes strongly reduced compared with nitrate nutrition. For this reason ammonium fed plants have (C-A) contents much less than the normal (van Tuil, 1965). In this way the balance-sheet reflects the form of nitrogen absorbed. When organic $\mathrm{N}$ is high, nitrate is present and the $(\mathrm{C}-\mathrm{A})$ content is normal, nitrate must have been in adequate supply. With high organic $\mathrm{N}$ and nitrate, a subnormal (C-A) content may have been caused by too low potassium or by too high chloride contents. When organic $\mathrm{N}$ is high, nitrate is absent and (C-A) is less than the normal even at moderate chloride contents, nitrogen must have been absorbed as ammonium. If in this case, nitrate is present, but the $(\mathrm{C}-\mathrm{A})$ content is still below the normal, plant nutrition may have changed recently from ammonium to nitrate as a result of nitrification or refertilization.

Many fertilizer formulas will be able to supply sufficient quantities of each of the elements for maximum growth, but will result in a subnormal (C-A) content and, in this way, create an unsatisfactory nutrient status for maximum growth. The balancesheet of ions and some knowledge of the characteristics of the plant species with respect to ion uptake and accumulation will often help to indicate in what respects the formulas should be changed to raise $(\mathrm{C}-\mathrm{A})$ in the plants to the normal value. Of course, this improvement of the ionic balance does not necessarily bring about maximum growth. Other factors, some related to ion supply as e.g. phosphorus, sulphate, minor elements, others to water, temperature, light and so on, may restrict growth, and thus reduce the size of the yield increment expected from the improvement of $(\mathrm{C}-\mathrm{A})$ or even make it zero.

From this it follows that plants with submaximum growth may have varying $(\mathrm{C}-\mathrm{A})$ contents, including the normal content. But maximum growth will invariably be associated with the normal $(\mathrm{C}-\mathrm{A})$ content.

For each plant species the evaluation of the normal organic salt content and the critical values for ion contents interfering with this normal value can only be made by means of experiments on yield and plant composition with systematic variations in fertilizer formulas. In the present investigation this was done for wheat. Of course, some caution is necessary when using definite critical values. The values given

have been inferred from the present results and, in addition, from those of earlier research on related species. They represent the best estimates available at present.

\section{Experimental}

\section{Experiment 1}

To sandy soil, poor in $\mathrm{N}$ and $\mathrm{K}$, sufficient calcium carbonate, magnesium oxide, magnesium sulphate and calcium phosphate was added to bring these constituents to an adequate level. The exchange capacity was $140 \mathrm{meq} . / \mathrm{kg}$.

The pots were filled with $7 \mathrm{~kg}$ of soil, and solutions of various salts were added in meq. quantities, as listed under the various treatments recorded in Table 1. In each pot, 24 seeds of the variety San Pastore were sown on April 9, 1964, and the pots placed in the greenhouse at about $20^{\circ} \mathrm{C}$. The plants were harvested on May 6 when in the fifth to sixth leaf stage.

The experiment was made in 4 replicates for dry weights. For plant analysis the material of the replicates was combined to form one sample for each treatment. 
Table I The salt ions, in meq. per pot, supplied to the pots of experiments 1 and 2. The yields are given as the mean of replicates with standard error of the mean

\begin{tabular}{|c|c|c|c|c|c|c|c|c|c|c|}
\hline \multirow[t]{2}{*}{ No. } & \multirow[t]{2}{*}{$K$} & \multirow[t]{2}{*}{$N a$} & \multirow[t]{2}{*}{$\mathrm{Ca}$} & \multirow[t]{2}{*}{$\mathrm{NH}_{4}$} & \multirow[t]{2}{*}{$\mathrm{NO}_{3}$} & \multirow[t]{2}{*}{$\mathrm{Cl}$} & \multirow[t]{2}{*}{$\mathrm{CO}_{3}$} & \multirow[t]{2}{*}{$\mathrm{SO}_{4}$} & \multicolumn{2}{|c|}{ Yield (g d.m. per pot) } \\
\hline & & & & & & & & & exp. $I$ & $\exp .2$ \\
\hline 1 & 40 & & & & 40 & & & & $7.5 \pm 0.2$ & $14.8 \pm 0.6$ \\
\hline 2 & 20 & & 20 & & 40 & & & & $7.1 \pm 0.1$ & $14.8 \pm 0.6$ \\
\hline 3 & 0 & & 40 & & 40 & & & & $4.3 \pm 0.2$ & $11.8 \pm 0.5$ \\
\hline 4 & 40 & & 40 & & 40 & 40 & & & $6.6 \pm 0.1$ & $15.7 \pm 0.7$ \\
\hline 5 & 20 & & 60 & & 40 & 40 & & & $6.8 \pm 0.4$ & $14.1 \pm 1.4$ \\
\hline 6 & 0 & & 80 & & 40 & 40 & & & $3.5 \pm 0.2$ & $11.8 \pm 0.2$ \\
\hline 7 & 80 & & 0 & & 40 & 40 & & & $6.5 \pm 0.2$ & $16.9 \pm 0.9$ \\
\hline 8 & 60 & & 20 & & 40 & 40 & & & $6.1 \pm 0.3$ & $15.1 \pm 0.6$ \\
\hline 9 & 40 & & 40 & & 40 & 40 & & & $6.5 \pm 0.4$ & $15.1 \pm 1.1$ \\
\hline 10 & 80 & & 0 & & 40 & & 40 & & $6.6 \pm 0.3$ & $13.6 \pm 0.5$ \\
\hline 11 & 60 & & 20 & & 40 & & 40 & & $7.6 \pm 0.3$ & $15.4 \pm 0.5$ \\
\hline 12 & 40 & & 40 & & 40 & & 40 & & $7.3 \pm 0.2$ & $14.9 \pm 0.4$ \\
\hline 13 & 20 & 20 & & & 40 & & & & $7.1 \pm 0.1$ & $14.7 \pm 0.6$ \\
\hline 14 & 10 & 30 & & & 40 & & & & $7.2 \pm 0.3$ & $14.8 \pm 0.3$ \\
\hline 15 & 0 & 40 & & & 40 & & & & $4.3 \pm 0.2$ & $12.3 \pm 0.5$ \\
\hline 16 & & & & & & & & & $1.6 \pm 0.1$ & $3.7 \pm 0.2$ \\
\hline 17 & 20 & & & & 20 & & & & $6.6 \pm 0.2$ & $11.9 \pm 0.5$ \\
\hline 18 & 0 & & 20 & & 20 & & & & $4.0 \pm 0.3$ & $10.0 \pm 0.4$ \\
\hline 19 & 40 & & & 40 & & & 40 & 40 & $6.6 \pm 0.3$ & - - \\
\hline 20 & 40 & & & 40 & & & 40 & 40 & $7.1 \pm 0.2$ & $14.2 \pm 0.4$ \\
\hline 21 & 40 & & & 20 & 20 & & 40 & & $8.3 \pm 0.2$ & $-\quad-$ \\
\hline 22 & 40 & & & 20 & 20 & & 40 & & $8.4 \pm 0.1$ & $14.9 \pm 0.6$ \\
\hline 23 & 40 & & & & 40 & & & & $7.6 \pm 0.3$ & $-\quad-$ \\
\hline
\end{tabular}

The results are listed in Table 1 and 2. The ammonium treatments were also made in the presence of 2-chloro-6(trichloromethyl) pyridine (N-serve). Although complete inhibition of nitrification of added ammonium by $\mathrm{N}$-serve was observed earlier (van Tuil and Lampe, 1964), it appeared ineffective in the present experiment.

\section{Experiment 2}

A soil-sand mixture, low in $\mathrm{N}$ and $\mathrm{K}$, and with an exchange capacity of $250 \mathrm{meq} / \mathrm{kg}$ was supplied with the basic dressing and with the additional salt treatments as described under experiment 1 . The pots were filled with $7 \mathrm{~kg}$ of the soil-sand mixture with basic dressing, salts were added according to the treatments, and 30 seeds were sown of the variety Mara on March 13, 1965. The pots were kept in the open at Kragujevac and harvested on May 18 at the fifth to sixth leaf stage. There were 5 replicates for dry weight, the combined material of each treatment was analysed. The treatments are given in Table 1 , together with the dry weights, and the results of plant analysis in Table 3.

\section{Experiment 3}

The pots were filled with the soil-sand mixture with basic dressing made as under experiment 2, and salt solutions were added according to the treatments listed in Table 4 and 5. The pots were sown with 30 seeds of the variety San Pastore on October 14, 1965 and kept in a greenhouse. The plants were cut on November 15 when in the 4th-leaf stage and another group on December 7 when in the 6th-leaf 
Table 2 Inorganic cations, their sum $(C)$, inorganic anions, including total phosphorus, their sum $(A)$, organic nitrogen ( $N$ org $)$ and the organic salt content $(C-A)$ in the plants of pot experiment 1 , made at Wageningen. All the data in meq./kg dry matter, Norg in mg atoms/kg dry matter. The first column shows the tratment numbers specified in Table 1.

\begin{tabular}{|c|c|c|c|c|c|c|c|c|c|c|c|c|}
\hline No. & $K$ & $N a$ & $M g$ & $\mathrm{Ca}$ & $C$ & $\mathrm{NO}_{3}$ & $\mathrm{Cl}$ & $\mathrm{H}_{2} \mathrm{PO}_{4}$ & $\mathrm{SO}_{4}$ & $A$ & $N_{\text {org }}$ & $(C-A)$ \\
\hline 1 & 1872 & 8 & 213 & 179 & 2274 & 856 & 160 & 280 & 95 & 1394 & 3304 & 880 \\
\hline 2 & 1713 & 8 & 246 & 254 & 2223 & 880 & 152 & 303 & 104 & 1440 & 3382 & 782 \\
\hline 3 & 434 & 52 & 666 & 518 & 1672 & 358 & 183 & 581 & 81 & 1203 & 3802 & 468 \\
\hline 4 & 1877 & 4 & 213 & 274 & 2369 & 664 & 620 & 300 & 60 & 1645 & 3495 & 724 \\
\hline 5 & 1596 & 4 & 246 & 319 & 2167 & 313 & 541 & 313 & 78 & 1548 & 3521 & 618 \\
\hline 6 & 506 & 34 & 592 & 613 & 1747 & 329 & 234 & 610 & 104 & 1278 & 3717 & 469 \\
\hline 7 & 2010 & 4 & 213 & 239 & 2467 & 700 & 580 & 306 & 59 & 1647 & 3517 & 820 \\
\hline 8 & 1982 & 4 & 213 & 254 & 2454 & 871 & 510 & 316 & 68 & 1765 & 3472 & 688 \\
\hline 9 & 1867 & 8 & 213 & 284 & 2373 & 661 & 597 & 309 & 68 & 1637 & 3464 & 736 \\
\hline 10 & 1897 & 8 & 197 & 179 & 2283 & 977 & 174 & 296 & 130 & 1579 & 3365 & 704 \\
\hline 11 & 1833 & 8 & 197 & 174 & 2214 & 835 & 157 & 300 & 103 & 1397 & 3279 & 817 \\
\hline 12 & 1838 & 8 & 213 & 204 & 2265 & 941 & 152 & 296 & 101 & 1493 & 3309 & 772 \\
\hline 13 & 1971 & 17 & 246 & 184 & 2420 & 879 & 157 & 296 & 130 & 1464 & 3350 & 955 \\
\hline 14 & 1263 & 65 & 328 & 239 & 1897 & 685 & 152 & 319 & 81 & 1239 & 3452 & 658 \\
\hline 15 & 455 & 347 & 534 & 319 & 1657 & 524 & 194 & 429 & 86 & 1234 & 3716 & 422 \\
\hline 16 & 746 & 8 & 320 & 319 & 1395 & 12 & 380 & 548 & 159 & 1101 & 1781 & 293 \\
\hline 17 & 1383 & 8 & 164 & 164 & 1721 & 95 & 166 & 335 & 202 & 799 & 2602 & 921 \\
\hline 18 & 404 & 56 & 641 & 459 & 1561 & 262 & 174 & 558 & 102 & 1089 & 3531 & 462 \\
\hline 19 & 1578 & 4 & 123 & 149 & 1855 & 64 & 186 & 464 & 401 & 1116 & 4004 & 738 \\
\hline 20 & 1567 & 4 & 106 & 109 & 1788 & 111 & 183 & 438 & 364 & 1098 & 3752 & 690 \\
\hline 21 & 1647 & 4 & 156 & 139 & 1947 & 519 & 152 & 326 & 132 & 1130 & 3321 & 817 \\
\hline 22 & 1716 & 8 & 156 & 129 & 2010 & 616 & 141 & 313 & 134 & 1204 & 3281 & 803 \\
\hline 23 & 1744 & 4 & 213 & 204 & 2167 & 717 & 152 & 300 & 79 & 1249 & 3259 & 917 \\
\hline
\end{tabular}

Table 3 Plant composition in experiment 2, made at Kragujevac. The treatment numbers refer to Table 1. For plant dry weights see Table 1.

\begin{tabular}{rrrrrrrrrrrrrr}
\hline$N o$. & $K$ & $N a$ & $M g$ & $C a$ & $C$ & $N O_{3}$ & $C l$ & $H_{2} P O_{4}$ & $S O_{1}$ & $A$ & $N_{\text {org }}$ & $(C-A)$ \\
1 & 1009 & 11 & 128 & 235 & 1383 & 6 & 150 & 186 & 117 & 459 & 2208 & 924 \\
2 & 886 & 13 & 157 & 261 & 1317 & 8 & 138 & 182 & 109 & 437 & 2085 & 880 \\
3 & 421 & 118 & 274 & 417 & 1230 & 10 & 153 & 205 & 101 & 469 & 2668 & 761 \\
4 & 1076 & 12 & 128 & 297 & 1513 & 5 & 458 & 179 & 81 & 723 & 1980 & 790 \\
5 & 948 & 14 & 154 & 325 & 1441 & 10 & 443 & 192 & 79 & 724 & 2190 & 717 \\
6 & 594 & 75 & 266 & 456 & 1391 & 6 & 337 & 176 & 71 & 590 & 2714 & 801 \\
7 & 1044 & 14 & 123 & 270 & 1451 & 6 & 463 & 146 & 81 & 696 & 2101 & 755 \\
8 & 1038 & 11 & 120 & 283 & 1452 & 8 & 456 & 119 & 89 & 672 & 1863 & 780 \\
9 & 1068 & 11 & 130 & 304 & 1513 & 8 & 499 & 182 & 89 & 778 & 2056 & 735 \\
10 & 1209 & 12 & 127 & 253 & 1601 & 11 & 159 & 186 & 123 & 479 & 2332 & 1122 \\
11 & 1041 & 10 & 123 & 253 & 1427 & 8 & 137 & 169 & 124 & 438 & 2099 & 989 \\
12 & 1007 & 15 & 144 & 301 & 1467 & 8 & 143 & 192 & 126 & 469 & 2178 & 998 \\
13 & 890 & 18 & 157 & 262 & 1327 & 6 & 125 & 192 & 122 & 445 & 2172 & 882 \\
14 & 694 & 48 & 177 & 283 & 1202 & 6 & 138 & 182 & 112 & 438 & 2980 & 764 \\
15 & 425 & 228 & 270 & 349 & 1272 & 6 & 159 & 211 & 108 & 484 & 2594 & 788 \\
16 & 573 & 61 & 109 & 243 & 986 & 8 & 182 & 119 & 68 & 377 & 1292 & 609 \\
17 & 773 & 12 & 122 & 221 & 1128 & 5 & 176 & 215 & 92 & 488 & 1545 & 640 \\
18 & 528 & 71 & 196 & 303 & 1098 & 5 & 180 & 189 & 210 & 584 & 1795 & 514 \\
20 & 1076 & 10 & 196 & 234 & 1516 & 8 & 127 & 189 & 145 & 469 & 1870 & 1047 \\
22 & 1013 & 10 & 197 & 250 & 1470 & 10 & 124 & 197 & 123 & 436 & 1947 & 1034 \\
\hline
\end{tabular}


stage. The experiment was made at Kragujevac. The first harvest comprised 6, the other 5 replicates. For analysis the material of the replicates was combined to one sample for each treatment. The results are listed in Table 5.

\section{Experiment 4}

This was made in the field at Kragujevac with the variety San Pastore. The plots were sown on October 24, 1964. On March 31, 1965100 plants were removed from each plot for the determination of dry weight and composition. The experiment was continued to ripeness and records were made of grain and straw yields.

Ammonium nitrate was applied: one-fourth before sowing, one-half at the onset of growth, and the remainder after sampling on March 31. Prior to sowing superphosphate and muriate of potash were applied according to the treatments (Table 6).

Table 4 Treatments and yields of experiment 3, made at Kragujevac

\begin{tabular}{|c|c|c|c|c|c|}
\hline \multirow[t]{2}{*}{ No. } & & \multicolumn{2}{|c|}{$\begin{array}{c}\text { Treatments } \\
\text { (meq. per pot) }\end{array}$} & \multicolumn{2}{|c|}{$\begin{array}{c}\text { Yield } \\
\left(\begin{array}{ll}g & \text { d.m. per pot }\end{array}\right)\end{array}$} \\
\hline & & $\mathrm{KNO}_{3}$ & $\mathrm{KHCO}_{3}$ & 4 leaves & 6 leaves \\
\hline 1 & 9 & 0 & 0 & $1.0 \pm 0.05$ & $1.7 \pm 0.04$ \\
\hline 2 & 10 & 20 & 0 & $2.3 \pm 0.10$ & $5.2 \pm 0.14$ \\
\hline 3 & 11 & 40 & 0 & $2.3 \pm 0.12$ & $6.1 \pm 0.26$ \\
\hline 4 & 12 & 60 & 0 & $2.2 \pm 0.14$ & $6.2 \pm 0.05$ \\
\hline 5 & 13 & 0 & 20 & $1.3 \pm 0.06$ & $1.8 \pm 0.05$ \\
\hline 6 & 14 & 20 & 20 & $2.3 \pm 0.17$ & $5.7 \pm 0.12$ \\
\hline 7 & 15 & 40 & 20 & $2.5 \pm 0.13$ & $6.3 \pm 0.27$ \\
\hline 8 & 16 & 60 & 20 & $2.4 \pm 0.11$ & $6.1 \pm 0.20$ \\
\hline
\end{tabular}

Table 5 Plant composition in experiment 3, made at Kragujevac. For treatments see Table 4.

\begin{tabular}{rrrrrrrrrrrrr} 
No. & $K$ & $N a$ & $M g$ & $C a$ & $C$ & $N O_{3}$ & $C l$ & $H_{2} P O_{4}$ & \multicolumn{1}{c}{$S O_{4}$} & $A$ & $N_{\text {org }}$ & $(C-A)$ \\
1 & 1205 & 42 & 273 & 304 & 1824 & 14 & 664 & 485 & 148 & 1311 & 2341 & 513 \\
2 & 1545 & 49 & 308 & 304 & 2206 & 777 & 383 & 328 & 46 & 1534 & 3642 & 672 \\
3 & 1654 & 35 & 289 & 335 & 2313 & 809 & 319 & 319 & 58 & 1505 & 3593 & 808 \\
4 & 1789 & 41 & 263 & 334 & 2427 & 858 & 300 & 312 & 36 & 1506 & 3642 & 921 \\
5 & 1271 & 28 & 290 & 302 & 1891 & 11 & 690 & 453 & 153 & 1307 & 2362 & 584 \\
6 & 1658 & 30 & 279 & 307 & 2274 & 857 & 359 & 325 & 52 & 1593 & 3408 & 681 \\
7 & 1742 & 32 & 263 & 349 & 2377 & 928 & 327 & 323 & 44 & 1622 & 3501 & 755 \\
8 & 1735 & 37 & 296 & 307 & 2375 & 856 & 306 & 325 & 128 & 1615 & 3541 & 760 \\
9 & 995 & 32 & 237 & 346 & 1610 & 11 & 626 & 393 & 181 & 1211 & 1589 & 399 \\
10 & 1240 & 32 & 220 & 315 & 1807 & 164 & 299 & 280 & 68 & 811 & 3045 & 996 \\
11 & 1498 & 32 & 238 & 315 & 2083 & 604 & 259 & 238 & 40 & 1141 & 3226 & 942 \\
12 & 1615 & 35 & 344 & 298 & 2222 & 741 & 259 & 241 & 97 & 1338 & 3233 & 954 \\
13 & 1089 & 32 & 229 & 261 & 1611 & 15 & 628 & 380 & 178 & 1201 & 1727 & 410 \\
14 & 1345 & 24 & 176 & 305 & 1850 & 159 & 310 & 394 & 113 & 976 & 3058 & 874 \\
15 & 1544 & 24 & 237 & 298 & 2103 & 639 & 259 & 257 & 128 & 1283 & 2387 & 820 \\
16 & 1613 & 28 & 246 & 325 & 2212 & 742 & 254 & 252 & 57 & 1305 & 2486 & 907 \\
& & & & & & & & & & & \\
\hline
\end{tabular}


Table 6 Treatments, plant weights in shooting stage, and final total dry weights and grain weights (14\% moisture basis) in experiment 4, made in the field at Kragujevac. For split application of $N$ compare text. $K$ was given as $40 \%$ muriate of potash, $N$ as ammonium nitrate limestone. The degree of lodging was estimated at two dates.

\begin{tabular}{|c|c|c|c|c|c|c|c|c|}
\hline \multirow[t]{2}{*}{ No. } & \multicolumn{3}{|c|}{$\begin{array}{l}\text { Treatments } \\
(\mathrm{kg} / \mathrm{ha})\end{array}$} & \multicolumn{2}{|c|}{$\%$ lodging } & \multirow{2}{*}{$\begin{array}{c}\text { Grams of } \\
\text { dry weight } \\
\text { per plant } \\
31 / 3\end{array}$} & \multicolumn{2}{|c|}{$\begin{array}{c}\text { Yield at ripeness } \\
(\text { ton } / \text { ha })\end{array}$} \\
\hline & $N$ & $P$ & $K$ & $31 / 5$ & $22 / 6$ & & total & grains \\
\hline 1 & - & - & - & & & 9.7 & 9.8 & 4.2 \\
\hline 2 & 100 & - & - & & & 11.3 & 11.6 & 5.1 \\
\hline 3 & - & 100 & - & & & 15.4 & 8.7 & 4.2 \\
\hline 4 & - & - & 100 & & & 15.7 & 8.3 & 4.1 \\
\hline 5 & 100 & 100 & - & & & 15.0 & 11.9 & 5.2 \\
\hline 6 & 100 & - & 100 & & & 12.9 & 10.4 & 5.2 \\
\hline 7 & - & 100 & 100 & & & 14.1 & 9.1 & 4.2 \\
\hline 8 & 50 & 100 & 100 & & & 15.4 & 10.9 & 5.0 \\
\hline 9 & 100 & 100 & 100 & & + & 21.2 & 12.0 & 5.1 \\
\hline 10 & 150 & 100 & 100 & 50 & 100 & 17.3 & 11.9 & 5.0 \\
\hline 11 & 200 & 100 & 100 & 70 & 100 & 18.9 & 11.5 & 4.6 \\
\hline 12 & 100 & 50 & 100 & & + & 15.9 & 12.1 & 5.1 \\
\hline 13 & 100 & 200 & 100 & & + & 24.3 & 11.9 & 5.2 \\
\hline 14 & 100 & 300 & 100 & & 100 & 17.5 & 12.7 & 5.1 \\
\hline 15 & 100 & 100 & 40 & 30 & 100 & 17.9 & 11.9 & 4.9 \\
\hline 16 & 100 & 100 & 160 & 50 & 100 & 19.1 & 11.9 & 5.3 \\
\hline 17 & 100 & 100 & 200 & & 100 & 13.7 & 12.1 & 5.1 \\
\hline 18 & 200 & 300 & 200 & 90 & 100 & 13.4 & 11.9 & 4.7 \\
\hline
\end{tabular}

\section{Discussion of the results}

The data on yields and (C-A) contents have been summarized in Fig. 2 for the experiments 1,2 and 3 . Most of the treatments in experiments 1 and 3 resulted in organic nitrogen contents of about 3500 meq. $/ \mathrm{kg}$ of dry matter. The $(\mathrm{C}-\mathrm{A})$ contents varied according to the treatments but did not exceed the value of $1000 \mathrm{meq} . / \mathrm{kg}$ dry matter which represents the normal organic salt content of gramineous plants.

The yield dropped when (C-A) fell below 750 meq. per $\mathrm{kg}$ dry matter owing to nitrate shortage (e.g. treatments 5 and 13 of exp. 3), or potassium shortage (e.g. treatments 3,6 and 18 of exp. 1 and 2) or both (treatment 16 of exp. 1 and 2). In treatments 1 and 10 of exp. 2, the low nitrate content indicates shortage, but nitrate had not come to exhaustion but shortly before harvesting, since the $(C-A)$ content was still high. Treatment 17 of exp. 1 gave similar results. But in treatment 17 of exp. 2, nitrate exhaustion had advanced much further since both the nitrate and the organic nitrogen contents were low, and the $(\mathrm{C}-\mathrm{A})$ content had dropped to a value significantly lower than the normal.

Some of the treatments had chloride in the fertilizer, others not. Since chloride is readily absorbed but not metabolized, its presence in the fertilizer is often associated with increased inorganic anion contents $A$. With chloride there may be some increase in the cation content $\mathrm{C}$ but this increase is less than the increment in $\mathrm{A}$ and the (C-A) content falls to a subnormal value. For instance, treatments $1,2,10$ and 11 without chloride gave average yields, (C-A) and chloride contents of $7.2 \mathrm{~g}, 795$ meq. $/ \mathrm{kg}$ and $160 \mathrm{meq} / \mathrm{kg}$, respectively, in experiment 1 , whereas treatments 4,5 , 7 and 8 with chloride yielded $6.5 \mathrm{~g}, 711 \mathrm{meq} . / \mathrm{kg}$ and $563 \mathrm{meq} . / \mathrm{kg}$. 
This effect of chloride was small compared with earlier results on barley and oats where the yield and (C-A) content were reduced by more than $25 \%$ by similar applications of chloride (de Wit et al., 1963).

In experiment 2 there was no effect of chloride on the yield. The low nitrate and organic nitrogen contents show that nitrogen had been short in the supply. These nitrogen deficient plants would not be expected to make additional growth when chloride was removed from the supply. The $(\mathrm{C}-\mathrm{A})$ content was raised but the yield remained unchanged at the submaximum level since it was restricted by shortage of nitrogen and not by $(\mathrm{C}-\mathrm{A})$.
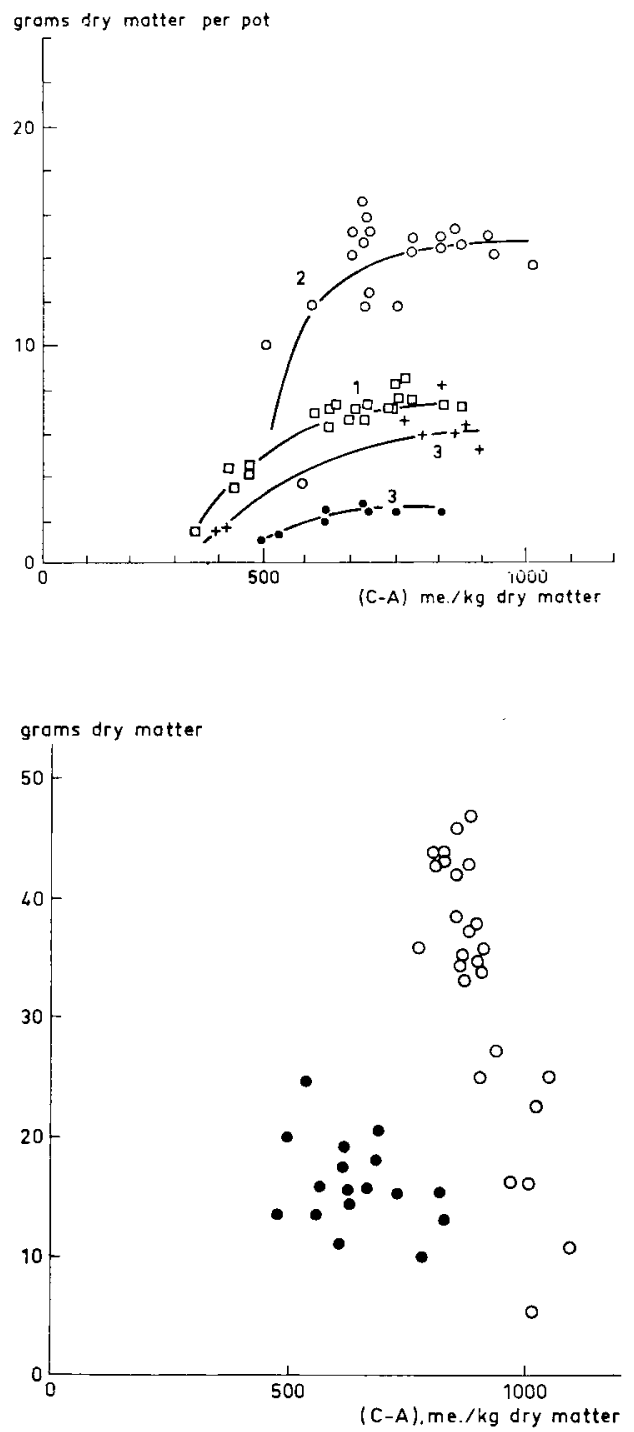

Fig. 2 Yields and organic salt content $(C-A)$ in the three pot experiments. The numbers correspond to those of the experiments mentioned in the text, with two growth stages for experiment 3 .

Fig. 3 Open circles: yields and $(\mathcal{C}-\boldsymbol{A})$ contents in corn, grown with varying amounts of micronutrients in the supply which caused the plant weights to vary considerably without much change in (C-A) contents. Data of Scharrer and Jung (1956).

Closed circles: results of experiment 4 , with differences in $(C-A)$ contents due to treatment, and variations in yield due to varying low phosphate levels. 
In some of the treatments of experiments 1 and 2 nitrogen was added as ammonium, but the results were comparable to the nitrate treatments. Previous research had shown that replacing nitrate by ammonium reduced both yield and $(C-A)$ content although sufficient supply with nutrients did, in fact, exist. The similarity between nitrate and ammonium in the present experiment should be related to a more rapid conversion of the added ammonium to nitrate by nitrification in the soil.

Another example of treatments affecting markedly the (C-A) content but not the yield is provided by the results of experiment 4 . The data, summarized by the closed circles in Fig. 3, show that there was no systematic change in yield when passing from treatments with subnormal $(C-A)$ contents to those where the normal $(C-A)$ content was reached. As pointed out before, this is indicative of some other factor unfavourable for growth which restricts dry matter production to a submaximum level. The data of Table 7 show that phosphate was lower than 200 meq. per kg dry matter with organic nitrogen contents greater than $3000 \mathrm{meq} . / \mathrm{kg}$ for all treatments. This indicates phosphate shortage. That phosphate was restricting growth became likely when the total amount of phosphate in the plants was plotted against the dry plant weights. Fig. 4 shows that there was a systematic increase of plant weight with the increase of the absolute amount of phosphate in the plants. Thus it seems that phosphate shortage had caused a consistent depression of the yield which prevented growth increments otherwise associated with increments of $(\mathrm{C}-\mathrm{A})$ towards the normal value.

Of course there are factors influencing the yield but not the $(\mathrm{C}-\mathrm{A})$ content. Treatments related to these factors may reduce the plant weight considerably without lowering the $(\mathrm{C}-\mathrm{A})$ content. An example is shown by the open circles in Fig. 3. It con-

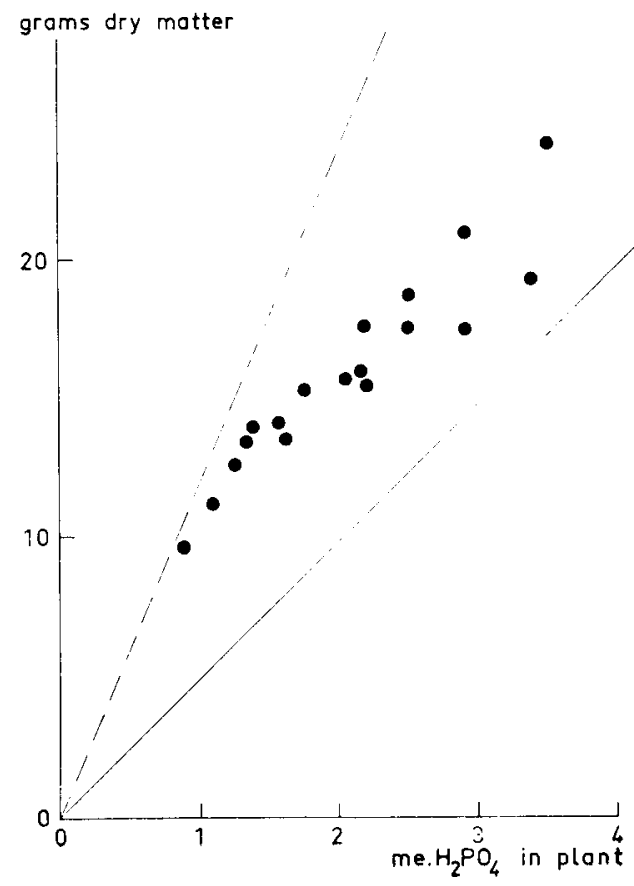

Fig. 4 Relation between the dry weights per plant and the total amounts of phosphate in the plants of experiment 4. The broken line shows the organic phosphate, calculated for the average level of $3500 \mathrm{meq}$. organic $\mathrm{N} / \mathrm{kg}$ dry matter, the solid line the phosphate requirement of 200 meq. $\mathrm{H}_{:} \mathrm{PO}_{*} / \mathrm{kg}$ dry matter for maximum growth. 
Table 7 Plant composition in experiment 4. The fields were sampled by removing 100 wheat plants from each treatment in the pre-shooting stage.

\begin{tabular}{rrrrrrrrrrrrr}
\hline$N o$. & $K$ & $N a$ & $M g$ & $C a$ & $C$ & $N O_{3}$ & $C l$ & $H_{2} P O_{4}$ & $S O_{4}$ & $A$ & $N_{\text {org }}$ & $(C-A)$ \\
1 & 913 & 34 & 208 & 275 & 1490 & 157 & 180 & 92 & 280 & 709 & 3257 & 781 \\
2 & 907 & 31 & 148 & 214 & 1300 & 186 & 152 & 96 & 257 & 691 & 3335 & 609 \\
3 & 849 & 28 & 148 & 225 & 1250 & 105 & 144 & 114 & 261 & 624 & 3509 & 626 \\
4 & 1072 & 27 & 131 & 230 & 1460 & 98 & 307 & 133 & 256 & 794 & 3945 & 666 \\
5 & 1150 & 23 & 107 & 230 & 1510 & 181 & 99 & 161 & 267 & 708 & 4205 & 802 \\
6 & 1176 & 23 & 140 & 214 & 1553 & 152 & 228 & 120 & 222 & 722 & 3526 & 831 \\
7 & 1021 & 31 & 164 & 180 & 1396 & 53 & 310 & 133 & 267 & 763 & 3618 & 633 \\
8 & 1163 & 29 & 171 & 252 & 1615 & 176 & 262 & 143 & 296 & 877 & 3781 & 738 \\
9 & 1166 & 33 & 67 & 239 & 1505 & 170 & 180 & 140 & 319 & 809 & 3573 & 696 \\
10 & 1100 & 33 & 156 & 264 & 1553 & 264 & 214 & 173 & 292 & 943 & 3622 & 610 \\
11 & 1019 & 41 & 164 & 259 & 1483 & 281 & 178 & 133 & 271 & 863 & 3676 & 620 \\
12 & 960 & 40 & 173 & 249 & 1422 & 184 & 240 & 134 & 298 & 856 & 3737 & 566 \\
13 & 945 & 46 & 173 & 262 & 1426 & 222 & 240 & 143 & 264 & 869 & 3671 & 557 \\
14 & 989 & 38 & - & - & - & 166 & 234 & 143 & 175 & 718 & 3591 & - \\
15 & 930 & 36 & 173 & 264 & 1403 & 194 & 194 & 123 & 210 & 721 & 3520 & 682 \\
16 & 926 & 28 & 173 & 252 & 1379 & 220 & 254 & 182 & 242 & 898 & 3737 & 481 \\
17 & 881 & 30 & 173 & 234 & 1318 & 167 & 254 & 95 & 251 & 767 & 3447 & 551 \\
18 & 860 & 32 & 181 & 264 & 1337 & 236 & 234 & 119 & 276 & 865 & 3585 & 472 \\
& & & & & & & & & & & & \\
\hline
\end{tabular}

Table 8 Test table for the nutritional status of wheat

\begin{tabular}{|c|c|c|c|c|}
\hline Test & & meq./kg d.m. & Comments & go to: \\
\hline \multirow[t]{2}{*}{1} & $\mathrm{NO}_{3}$ & above 100 & $\begin{array}{l}\text { sufficient } \mathrm{N} \text { for maximum growth, but undesirably } \\
\text { high in the pre-shooting stage }\end{array}$ & 2 \\
\hline & & below & & 3 \\
\hline \multirow[t]{2}{*}{2} & $(\mathrm{C}-\mathrm{A})$ & above & & 4 \\
\hline & & below & & 5 \\
\hline \multirow[t]{2}{*}{3} & $(\mathrm{C}-\mathrm{A})$ & above & $\begin{array}{l}\text { moderate } \mathbf{N} \text { shortage, but desirable in the pre- } \\
\text { shooting stage }\end{array}$ & 4 \\
\hline & & below & & 8 \\
\hline \multirow[t]{3}{*}{4} & $\mathbf{K}$ & above 800 & & 13 \\
\hline & & $500-800$ & $\begin{array}{l}\mathrm{K} \text { shortage if } \mathrm{N} \text { is applied } \\
\text { after shooting }\end{array}$ & 13 \\
\hline & & below 500 & K shortage & 13 \\
\hline \multirow[t]{3}{*}{5} & $\mathbf{A}$ & above 1500 & $\begin{array}{l}\text { too high, the anions } \mathrm{NO}_{3}, \mathrm{Cl}, \mathrm{H}_{2} \mathrm{PO}_{4}, \mathrm{SO}_{4} \text { are un- } \\
\text { necessarily high if above } 500,200,300 \text { and } 100\end{array}$ & 6 \\
\hline & & $1500-800$ & & 6 \\
\hline & & below 800 & & 7 \\
\hline \multirow[t]{3}{*}{6} & $\mathbf{K}$ & above 1100 & & 13 \\
\hline & & $1100-800$ & $\begin{array}{l}\text { if } A \text { cannot be reduced, }(\mathrm{C}-\mathrm{A}) \text { may be increased } \\
\text { by raising the } \mathrm{K} \text { level }\end{array}$ & 13 \\
\hline & & below & $\mathrm{K}$ shortage & 13 \\
\hline \multirow[t]{2}{*}{7} & $\mathbf{K}$ & above & & 13 \\
\hline & & below 800 & $\mathrm{~K}$ shortage & 13 \\
\hline \multirow[t]{3}{*}{8} & $\mathbf{N}_{\text {org }}$ & above 3000 & & 9 \\
\hline & & $3000-2000$ & $\mathrm{~N}$ shortage, but desirable in the pre-shooting stage & 10 \\
\hline & & below 2000 & N shortage & 10 \\
\hline \multirow[t]{2}{*}{9} & $(\mathrm{C}-\mathrm{A})$ & above 500 & history of ammonium uptake & 11 \\
\hline & & below & too much ammonium absorption & 11 \\
\hline \multirow[t]{2}{*}{10} & $\mathbf{K}$ & above & & 12 \\
\hline & & below & K shortage & 12 \\
\hline \multirow[t]{2}{*}{11} & $\mathbf{K}$ & above & & 12 \\
\hline & & below & K shortage & 12 \\
\hline 12 & $\mathrm{Cl}$ & above & too much $\mathrm{Cl}$ & \\
\hline 13 & & below & $\begin{array}{l}\mathrm{H}_{2} \mathrm{PO}_{4}, \mathrm{SO}_{4}, \mathrm{Mg}, \mathrm{Ca} \text { shortage if below } 200,20, \\
100,100 \mathrm{meq} . / \mathrm{kg}\end{array}$ & 13 \\
\hline
\end{tabular}


cerns maize plants grown with varying supplies of micronutrients. These factors may also be related to the supply with major elements included in the ionic balance, as e.g. sulphate and phosphate shortage, which interfere with growth but not with the (C-A) content. Their status can be inferred from the results of chemical analysis.

The final make-up of the balance gives a systematic review of the contents of each of the elements which can be compared with the critical values. The additive values for $\mathrm{C}, \mathrm{A}$ and $(\mathrm{C}-\mathrm{A})$ can be used for defining the status of $(\mathrm{C}-\mathrm{A})$ with respect to the normal value. Sufficient knowledge on the effect of added fertilizers on composition of the plant species concerned may render it possible to suggest changes in nutrition which may improve the ionic balance.

For young wheat plants the present experience has been summarized in Table 8 , to be used as a key for the nutritional status. The reader should bear in mind that for values close to the limits the alternative course should also be followed, and an intermediate conclusion should be drawn. For instance, treatment 9 of experiment 1 shows a too high anion content $A$ caused by excess chloride. But $(C-A)$ is close to the limit and the alternative course without excess chloride is also applicable, which shows that the excess was not serious. A similar conclusion applies to the data of treatment 7 .

When the supply changes from ammonium to nitrate, a transition stage may be encountered where the $(C-A)$ content is low and the nitrate content high. Table 8 reveals this condition when applied to the data of e.g. treatment 15 of exp. 4, referring to plants grown in the early season with ammonium nitrate as the fertilizer.

In many cases there may be other evidence that the soil used supplies sufficient calcium, magnesium, phosphate and sulphate for maximum growth. If so, the procedure may be simplified by confining plant analysis to nitrate, potassium and ashalkalinity, and calculating (C-A) by subtracting nitrate from ash-alkalinity (van Tuil et al., 1964). When total nitrogen is also determined the nutrient status can be examined for potassium, nitrogen and $(\mathrm{C}-\mathrm{A})$. Test 5 cannot be made, but when potassium values are greater than 1100 meq. $/ \mathrm{kg}$ dry matter it is likely that the anion contents $\mathrm{A}$ are too high and correspondingly have increased the plant need for cation uptake.

\section{References}

Broeshart, H. and Schouwenburg, J. C. van, 1961. Early diagnosis of mineral deficiencies by means of plant analysis. Neth. J. Agr. Sci., 9: 108-118.

Burg, P. F. J. van, 1966. Nitrate as an indicator of the nitrogen-nutrition status of grass. Proc. Xth Intern. Grassland Congr., Helsinki, pp. 267-272.

Dijkshoorn, W., 1958. Nitrate accumulation, nitrogen balance and cation-anion ratio during the regrowth of perennial ryegrass. Neth. J. Agr. Sci., $6: 211-221$.

Dijkshoorn, W. and Lampe, J. E. M., 1961. Phosphorus fractions in perennial ryegrass. Jaarb. I.B.S., Wageningen 1961, pp. 101-106.

Dijkshoorn, W. and Wijk, A. L. van, 1967. The sulphur requirements of plants as evidenced by the $\mathrm{S} / \mathrm{N}$ ratio in the organic substance. A review of published data. Plant Soil, 26: 129-157.

Garner, W. W., McMurtrey, J. E., Bowling, J. D. and Moss, E. G., 1930. Magnesium and calcium requirements of the tobacco crop. J. Agr. Res., 40: 145-168.

Jonker, J. J. en Jong, G. J. de, 1966. Invloed van gedeelde stikstofgiften en van CCC op de opbrengst van granen in Oostelijk Flevoland. Stikstof, 51: 160-173.

Key, J. L., Kurtz, L. T. and Tucker, B. B., 1962. Influence of ratio of exchangeable calciummagnesium on yield and composition of soybeans and corn. Soil Sci., 93: 265-270.

Lehr, J. J. and Wybenga, J. M., 1958. Exploratory pot experiments on sensitiveness of different crops to sodium : barley. Plant Soil, 9:237-253. 
Lundegårdh, H., 1951. Leaf analysis. London.

Scharrer, K. und Jung, J., 1956. Ưber den Einfluss von Mangan, Kupfer, Zink, Eisen, Bor, Molybdän und Kobalt auf die Mineralstoffaufnahme bei Mais und Ackerbohnen. Z. Pflanzenernähr., Düng., Bodenk., 75: 47-66.

Sokolov, A. V., 1945. Influence of feeding conditions upon the plant content of various phosphorus compounds, Compt. Rend. Acad. Sci. U.S.S.R. (Dokl. Akad. Nauk. S.S.S.R.), 49: 123-126.

Tuil, H. D. W. van, 1965. Organic salts in plants in relation to nutrition and growth. Agr. Res. Rept. Wageningen, No. 657.

Tuil, H. D. W. van and Lampe, J. E. M., 1964. Control of nitrification by 2-chloro-6-(trichloromethyl)pyridine. Jaarb. I.B.S., Wageningen 1964, pp. 161-163.

Tuil, H. D. W. van, Lampe, J. E. M. and Dijkshoorn, W., 1964. The possibility of relating the ash-kalinity to the organic salt content. Jaarb. I.B.S., Wageningen, pp. 157-160.

Ulrich, A. and Ohki, K., 1956. Chloride, bromide and sodium as nutrients for sugar beet. Plant Physiol., 31 : 171-181.

Wit, C. T. de, Dijkshoorn, W. and Noggle, J. C., 1963. Ionic balance and growth of plants. Agr. Res. Rept. Wageningen, No. 69.15. 